\title{
Preliminary Study to Strengthening Strategic Environmental Assessment to Implement Green Infrastructure Concept in Waste Management
}

\author{
Dwi Sri Nuryanti ${ }^{1 *}$, Maryono Maryono ${ }^{2,4}$, and Fuad Muhammad ${ }^{3,4}$ \\ ${ }^{1}$ Master of Environmental Science, School of Postgraduate Studies, Diponegoro University, \\ Semarang, Indonesia \\ ${ }^{2}$ Department of Urban and Regional Planning, Faculty of Engineering, Diponegoro University, \\ Semarang, Indonesia \\ ${ }^{3}$ Biology Department, Faculty of Science and Mathematics, Diponegoro University, Semarang, \\ Indonesia \\ ${ }^{4}$ Center for Green Infrastructure Resilience Development, School of Postgraduate Studies, \\ Diponegoro University, Semarang, Indonesia
}

\begin{abstract}
Waste is a major problem in Central Java Province, especially in urban areas. The development of green infrastructure in waste management is the best solution to overcome this waste problem. This paper discusses whether environmental waste management has been adopted in strategic environmental assessment. By using qualitative descriptive analysis, the research was carried out through literature review and content analysis of strategic environmental assessment reports that have been published in Central Java Province. The result show that most strategic environmental assessments have recommended green infrastructure in waste management. However, it needs to be investigated further concerning its implementation. Green infrastructure in waste management must be included in spatial planning policy which integrated with strategic environmental assessment.
\end{abstract}

\section{Introduction}

The increase in population and its increasingly diverse activities have implications for various kinds of environmental problems. One of these environmental problems is the waste problem which is a concern of the world's population due to excessive consumption which has increased significantly in the last few decades [1]. Waste management is one of the major challenges that urban areas in developing countries have to face. Currently in Indonesia, only $86.7 \%$ of households, both rural and urban, have access to solid waste management, $81.2 \%$ of unsorted waste is still $81.2 \%$ and only $60 \%$ of existing household waste is transported to the next process [2,3]. Green infrastructure planning is an approach to building infrastructure with environmental consideration from a policy viewpoint to implementation and maintenance and considering the social quality of cities [4]. The European Commission defines green infrastructure as a planned network of natural and semi-natural areas designed

* Corresponding author: dwisn2234@gmail.com 
and managed to provide a variety of ecosystem services [4]. Another definition states that green infrastructure is not only visually green but is supported by ecological functions and infrastructure with more specific sustainability functions, such as renewable energy $[5,6]$. green infrastructure is a path to propose an approach that combines a visually and functionally visible green infrastructure as long as the results contribute to sustainability. Integrating green infrastructure in spatial planning can result in improved environmental services and result in a more resilient environment. However, this component has not been taken into consideration in spatial planning in Indonesia and has not been accommodated in Act Number 26 of 2007 concerning Spatial Planning [7]. The implication for developing infrastructure is that there is still a lack of information and policy for maintenance infrastructure environmental sound, for example in landfill maintenance due to overs capacity and methane emission [8]. Moreover successful of green infrastructure will influence not only rural-urban sector development but also other sector such as tourism [9].

To integrate environmental indicators or components in spatial planning, a strategic environmental assessment (SEA) is compiled. This study identifies whether the concept of green infrastructure in waste management has been adopted in SEA and analyzes the potential for developing green infrastructure in waste management in SEA.

\section{Method}

This research use qualitative descriptive analysis based on literature review of nine papers on previous research related to the development of the green infrastructure concept in waste management. Then, case studies were conducted in ten regions ( 8 regency and 2 city) in Central Java i.e. Batang, Boyolali, Cilacap, Grobogan, Jepara, Klaten, Purbalingga, Wonogiri, Surakarta and Semarang City to see whether they had adopted the green infrastructure concept in SEA to be integrated into their regional spatial planning. For this reason, content analysis was carried out on 10 SEA reports that had been made. The green infrastructure concept under study is emphasized on waste management.

\section{Results and Discussion}

\subsection{Preliminary assessement for the implementation of green infrastructure concept in waste management}

The concept of green infrastructure does not only refer to visualization, but emphasizes ecological functions by increasing environmental services [5,6]. In Act Number 18 of 2008 concerning waste management, it is stated that in the implementation of waste management it is carried out based on the principle of sustainability. This principle of sustainability implies that waste management is carried out using environmentally friendly methods and techniques so that it does not harm public health and the environment, both for present and future generations. This concept is in line with the development of a green infrastructure concept that is oriented towards improving environmental services for sustainability.

Based on the law, waste management is a systematic, comprehensive, and sustainable activity that includes waste reduction and handling. The mechanism for distributing waste in Indonesia is that waste from settlements and trade and service areas are transported to temporary waste shelters and then taken to the final waste processing site (landfill). Most of the landfill waste management in Indonesia uses open dumping and landfill methods, but there are also other methods, namely composting, burning, sorting, and recycling, although they are not widely used. In Central Java, around $35 \%$ of final waste processing still uses the open dumping system, and only $6 \%$ has utilized it sanitary landfill as presented in table 1 . In 
an open dumping system, garbage is disposed of in an open space. This system is not recommended because it is very detrimental to the environment [10]. The controlled landfill system is an upgrade from open dumping with the landfill dumping soil every seven days. Meanwhile, the sanitary landfill system is a means of backfilling waste to the environment which is systematically prepared and operated. In this system, waste is piled up and compacted, then covered with a layer of ground cover every day [11].

Table 1. Types of Landfill in Central Java.

\begin{tabular}{|l|l|l|}
\hline Type of landfill & Number of Landfill & Percentage (\%) \\
\hline Open dumping & 17 & 35 \\
\hline Controlled landfill & 29 & 59 \\
\hline Sanitary landfill & 3 & 6 \\
\hline Amount & 49 & 100 \\
\hline
\end{tabular}

Source: Environment and Forestry Service of Central Java Province, 2019

There are four types of landfills commonly used around the world namely dry-type modern landfills, wet-type modern landfills, above-ground dumpsites, high-permeability land raises [12]. In his research, Madon found that wet-type modern landfills are the best type of landfill and cause little contamination to aquifers. This type is engineered with the extraction, collection, and treatment of leachate and landfill gas as well as water recirculation and waste stabilization activities after the closure of the landfill.

Compared to developed countries, Indonesia is still far behind with most of the waste management carried out by controlled landfills, and there are still around 35\% of landfills in Central Java that use an open dumping system. We cannot deny that open dumping will harm the environment. According to $[13,14]$ open dumping systems threaten public health and the environment, affect the geology and climate of an area, and the long-term potential for contamination due to leachate and landfill gas. Gas produced from open dumping system waste contributes to greenhouse gases which cause global warming [15]. In [16] shows that waste processing using the semi aerobic landfill system or the Fukuoka method can reduce $40 \%$ of greens house gases emissions when compared to the application of an open dumping system. [17] has identified the life cycle assessment performance of six landfill technologies, namely open dumping, conventional landfill, semi-aerobic landfill, standard bioreactor landfill, and flushing bioreactor landfill. In his research, Manfredi stated that the use of gas for alternative energy plays an important role in the system because it leads to emission savings and the potential environmental impact can be avoided. He also stated that the aerobic semi technology shows good environmental performance due to the reduced leachate production due to the waste aerobic process.

Technology for processing waste into alternative energy already exists in several areas in Central Java, but the amount is still very limited. An example is the use of alternative energy from a landfill, which is a power plant from methane gas at Jatibarang landfill in Semarang City. Jatibarang landfill gas production is estimated at $600 \mathrm{~m} 3$ / hour which can be converted into 1.3 MW[18]. This activity has implemented a green infrastructure concept that can reduce the impact of methane gas on the environment and as an alternative energy source.

\subsection{Preliminary analysis to strengthening SEA in implementing green infrastructure concept in waste management}

SEA is generally defined as a structured and participatory process to integrate environmental issues into decision-making [19]. The SEA approach is recognized as an important instrument in including environmental components in decision making or policies, plans, or 
programs [20] and is considered a good approach to achieving sustainable development goals [21].

Based on government regulation concerning SEA, the implementation of SEA in Indonesia includes three stages. The first stage is the making and implementation of SEA. This stage includes three activities, namely: (1) assessment of the impact of the policies, plans, or programs (PPP) on environmental conditions, (2) Alternative PPP improvements, (3) preparation of recommendations for improvement for PPP decision making that integrate sustainable development. In the first stage, this is an important part of the preparation of SEA where the sustainable aspect is considered in the formulation of the PPP. The six contents of SEA that must be analyzed in SEA are (a) the carrying capacity and assimilative capacity of the environment, (b) estimates of environmental impacts and risks, (c) performance of ecosystem services, (d) efficient use of natural resources, (e) the level of vulnerability and capacity to adapt to climate change, and (f) level of resilience and potential of biodiversity. The second stage is quality assurance and documentation of SEA. Quality assurance is carried out through a mandatory assessment by the compilers of the PPP to ensure that the quality and process of making and implementing SEA are carried out following applicable regulations. The third stage is the validation of SEA which is carried out to ensure that quality assurance has been carried out accountably and can be held accountable to the public.

SEA which is prepared by integrating environmental components is expected to provide benefits for sustainable development. Completely [22] identify five benefits of SEA, namely (1) consideration of a broader impact and formulation of alternative improvements to policy plans or programs, (2) proactively SEA to support in realizing sustainable development, (3) Overcoming Environmental Impact Assessment (EIA) weaknesses, (4) environmental considerations at the level of decision making, (5) allows for public participation.

The concept of green infrastructure in solid waste management emphasizes the achievement of sustainable development goals, especially in environmental aspects. The green infrastructure concept in solid waste management can be more effective if it is planned at the early stages of the planning process and is integrated into policies, plans, and / or programs that have integrated SEA. The benefits obtained from integrating the green infrastructure concept in waste management in SEA are explained as follows:

1. there is consideration of a broader impact and formulation of alternative improvements to policy plans or programs

The consideration of the impact of waste management can be reviewed earlier, namely at the planning stage before the landfill location is determined. According to [11] in determining the location of a landfill with a sanitary landfill system, it is necessary to consider the geological and topographic structure of the soil, groundwater depth, soil layer, and rock layers. Landfills can have a detrimental impact on groundwater, so the selection of a landfill site must be appropriate, not in a disaster-prone area, not disturbing the hydrological function of groundwater and considering its distance from settlements. SEA can provide an alternative location that is suitable for waste management so that it is in accordance with the desired green infrastructure concept.

2. SEA proactively becomes a supporter in realizing sustainable development

Waste management with the concept of green infrastructure integrated into SEA is expected to support the sustainable development goals of goals 11 th and 12th. The 11th SDG's objectives are to make cities and settlements inclusive, safe, resilient, and sustainable with indicators including the percentage of handled urban waste, the number of green cities that develop and implement green waste in metropolitan urban areas, while goal 12 th is to ensure sustainable production and consumption patterns with an indicator of the amount of recycled waste generation. 


\section{Overcoming EIA weaknesses}

It is important to determine the location of the landfill to minimize the impact that occurs. Following SNI 03-3241-1994 concerning Procedures for Selecting a Location for Final Disposal of Waste, prospective landfill sites must meet regional criteria including geological, hydrogeological, land slope, distance from airfields, nature reserves, floods, and other criteria in the form of climate, utility, biological environment, soil conditions, demographics, administrative boundaries, noise, smells, aesthetics, and economy. SEA can provide alternative landfill locations that are following the green infrastructure concept. Determination of the planned landfill location, as well as environment-friendly considerations carried out in SEA, contributed to the EIA study so that the EIA study was made simpler.

4. Environmental considerations at the level of decision making

The importance of the green infrastructure concept included in the SEA is that this consideration will affect a higher level namely at the policy level. If the EIA study will only affect a project, then a study on SEA can influence policies, plans, or programs that will become binding regional regulations.

5. Allows for public participation

Another advantage obtained is minimizing the potential for conflict when the activities are to be carried out because the SEA has accommodated the public consultation process. The community or NGOs will participate in providing input or rebuttal to the SEA preparation process. Moreover, if the transfer of information related to green infrastructure can be conveyed clearly to the public, of course, there will not be much rejection from them. The development of the green infrastructure concept for waste management in SEA provides many benefits. In [23] stated that the SEA policy framework as an effective waste management method is implemented to achieve important strategies towards waste reduction, conservation of landfill areas, stabilization and elimination of hazardous substances in waste, and optimal energy treatment. The green infrastructure concept in waste management has been integrated into SEA in Central Java. Table 2 illustrates that SEA in Central Java has considered the green infrastructure concept in its study. However, the studies carried out on the aspects were not sufficiently detailed as expected, so that the benefits obtained did not meet the five aspects discussed in subsection 3.2.

Table 2. Preliminary analysis for the implementation of SEA in Spatial Planning to implement green infrastructure concept in waste management in Central Java.

\begin{tabular}{|l|c|c|c|c|}
\hline $\begin{array}{c}\text { Regency / } \\
\text { City }\end{array}$ & $\begin{array}{c}\text { Strategic } \\
\text { Issues about } \\
\text { waste } \\
\text { management }\end{array}$ & $\begin{array}{c}\text { PPP for } \\
\text { waste } \\
\text { management }\end{array}$ & $\begin{array}{c}\text { Recommendations } \\
\text { regarding waste } \\
\text { management }\end{array}$ & $\begin{array}{c}\text { Integrating } \\
\text { the green } \\
\text { infrastructure } \\
\text { concept }\end{array}$ \\
\hline Batang & Yes & - & $\begin{array}{c}\text { - integrated waste } \\
\text { treatment plant (IWTP) } \\
\text { construction } \\
\text { independent waste } \\
\text { management by the } \\
\text { community (waste bank) }\end{array}$ & Yes \\
\hline Boyolali & Yes & - & $\begin{array}{l}\text { - Provision of a waste } \\
\text { management system in } \\
\text { residential areas }\end{array}$ & No \\
\hline Cilacap & Yes & - & $\begin{array}{l}\text { System development } \\
\text { Solid waste management } \\
\text { with increased roles } \\
\text { society in reduction of }\end{array}$ & Yes \\
\hline
\end{tabular}




\begin{tabular}{|c|c|c|c|c|}
\hline $\begin{array}{l}\text { Regency / } \\
\text { City }\end{array}$ & $\begin{array}{c}\text { Strategic } \\
\text { Issues about } \\
\text { waste } \\
\text { management }\end{array}$ & $\begin{array}{c}\text { PPP for } \\
\text { waste } \\
\text { management }\end{array}$ & $\begin{array}{l}\text { Recommendations } \\
\text { regarding waste } \\
\text { management }\end{array}$ & $\begin{array}{l}\text { Integrating } \\
\text { the green } \\
\text { infrastructure } \\
\text { concept }\end{array}$ \\
\hline & & & $\begin{array}{ll}\text { waste } & \text { from } \\
\text { the source } & \\
\end{array}$ & \\
\hline \multirow[t]{2}{*}{ Grobogan } & Yes & Yes & $\begin{array}{l}\text { - SEA has not provided an } \\
\text { alternative location }\end{array}$ & No \\
\hline & & & $\begin{array}{l}\text { - Provide directions for the } \\
\text { landfill to be carried out } \\
\text { in the right location and } \\
\text { system so that it does not } \\
\text { become a new problem } \\
\text { that can damage existing } \\
\text { natural resources, } \\
\text { especially the } \\
\text { availability of clean } \\
\text { water }\end{array}$ & \\
\hline Jepara & Yes & Yes & $\begin{array}{l}\text { - Waste management is } \\
\text { carried out from the } \\
\text { source to the downstream } \\
\text { through the } \\
\text { implementation of 3Rs } \\
\text { with waste treatment } \\
\text { plant (WTP) with 3R } \\
\text { facilities, at the sub- } \\
\text { district level or more } \\
\text { broadly through IWTP } \\
\text { facilities and at } \\
\text { subdistrict level through } \\
\text { landfill that applies waste } \\
\text { reduction techniques } \\
\text { such as composting, } \\
\text { reuse, and for energy } \\
\text { (energy waste) according } \\
\text { to the characteristics of } \\
\text { waste, other than the use } \\
\text { of sanitary landfills. }\end{array}$ & Yes \\
\hline Klaten & Yes & Yes & $\begin{array}{l}\text { - Increase in landfill with } \\
\text { vegetation } \\
\text { - Far from settlements } \\
\text { - Complies with EIA } \\
\text { - Landfill development } \\
\text { with a waste treatment } \\
\text { unit }\end{array}$ & Yes \\
\hline $\begin{array}{l}\text { Semarang } \\
\text { city }\end{array}$ & Yes & - & $\begin{array}{l}\text { - Landfill management } \\
\text { plan that is oriented } \\
\text { towards waste reduction } \\
\text { through 3R efforts }\end{array}$ & Yes \\
\hline
\end{tabular}




\begin{tabular}{|c|c|c|c|c|}
\hline $\begin{array}{l}\text { Regency / } \\
\text { City }\end{array}$ & $\begin{array}{c}\text { Strategic } \\
\text { Issues about } \\
\text { waste } \\
\text { management }\end{array}$ & $\begin{array}{c}\text { PPP for } \\
\text { waste } \\
\text { management }\end{array}$ & $\begin{array}{c}\text { Recommendations } \\
\text { regarding waste } \\
\text { management }\end{array}$ & $\begin{array}{c}\text { Integrating } \\
\text { the green } \\
\text { infrastructure } \\
\text { concept }\end{array}$ \\
\hline & & & $\begin{array}{l}\text { - Landfill management for } \\
\text { energy sources (waste to } \\
\text { energy) } \\
\text { - Landfill with a sanitary } \\
\text { landfill system. } \\
\text { - Anticipating regional } \\
\text { waste management given } \\
\text { the limited land in the } \\
\text { future. } \\
\text { - there is an Intermediate } \\
\text { Treatment Facility (ITF) } \\
\text { that approaches the } \\
\text { source }\end{array}$ & \\
\hline Surakarta & Yes & Yes & $\begin{array}{l}\text { - Waste power plant } \\
\text { development } \\
\text { - } 3 \mathrm{R} \text { sorting of waste } \\
\text { (Reuse, } \\
\text { Reduce) } \\
\text { - Waste management with } \\
\text { friendly technology } \\
\text { (incinerator, plasma } \\
\text { gasification, pyrolysis) } \\
\text { - Build cooperation with } \\
\text { the surrounding area } \\
\text { - Optimizing waste } \\
\text { transportation up to } \\
100 \% \text { Mane the metal waste } \\
\text { - Manage } \\
\text { produced by Waste } \\
\text { power plant }\end{array}$ & Yes \\
\hline Purbalingga & Yes & - & $\begin{array}{l}\text { - Waste management is } \\
\text { carried out from the } \\
\text { source to the } \\
\text { downstream through the } \\
\text { implementation of 3Rs } \\
\text { with WTP 3R, IWTP, } \\
\text { and landfill facilities that } \\
\text { apply waste reduction } \\
\text { techniques such as } \\
\text { composting, reuse, and } \\
\text { for energy (waste to } \\
\text { energy) according to the } \\
\text { characteristics of the } \\
\text { trash } \\
\text { - use of sanitary landfills }\end{array}$ & Yes \\
\hline Wonogiri & Yes & Yes & - No & No \\
\hline
\end{tabular}


Based on the 10 samples of SEA reports, 5 regions assess PPP of solid waste networks as PPP having an impact on the environment. However, not all of the proposed SEA recommendations are operational and are still general directions. SEA has not been able to provide an appropriate location for landfill and IWTP activities. Grobogan Regency plans to develop a landfill with a sanitary landfill system. Even though it has given consideration that the prospective landfill site is safe, it has not comprehensively reviewed the requirements for the landfill as in SNI 03-3241-1994. Wonogiri Regency also plans to carry out the construction or expansion of the landfill, but there is no consideration of the green infrastructure concept in its SEA. However, despite using a relatively simple study, 7 of 10 SEA have provided green infrastructure recommendations for the waste management system.

By integrating the green infrastructure concept in SEA, it is hoped that it can provide appropriate location directions, propose a waste management system that is most suitable for regional conditions that adopt the infrastructure concept, and emphasizes the green infrastructure concept at the regional policy level through regional regulations. The determination of the location according to the characteristics of the area as well as the impact assessment that has been carried out in the SEA process makes the implementation of EIA more effective. However, these benefits can be obtained only if the study in SEA has been carried out in detail and comprehensively.

\section{Conclusion}

Based on the discussion previously described, it was concluded that the development of the green infrastructure concept provides many benefits for sustainable development. The green infrastructure concept in solid waste management can be more effective if it is planned at the early stages of the planning process and is integrated into PPP that has integrated with SEA. Although most areas in Central Java have formulated green infrastructure recommendations in waste management, the recommendations given are general directions that are less operational. Issues related to solid waste are considered a priority issue that must be resolved immediately, however, the study of solid waste in SEA is not in-depth and is not comprehensive enough to integrate the green infrastructure concept in it. Landfill implementation can be effective only if the SEA is detailed and comprehensive.

\section{References}

1 L. da Silva, P.D. Marques Prietto, and E. Pavan Korf, J. Clean. Prod., 237, (2019).

2 E. Damanhuri, A Future Prospect of Municipal Solid Waste Management in Indonesia, in: 5th Asian-Pasific Landfill Symp. Sapporo, Japan, (2008).

3 Setyowati and Mulasari, Kesmas, 7, 563 (2013).

4 A. Cheshmehzangi, C. Butters, L. Xie, and A. Dawodu, Urban For. Urban Green., 59, 1-9 (2021).

$5 \quad$ H. Wright, Local Environ., 16, 1003-1019 (2011).

$6 \quad$ I.C. Mell, Local Environ., 18, 152-166 (2013).

7 S. Maryati, A.N.S. Humaira, and P. Adianti, Procedia-Soc. Behav. Sci., 227, 617622 (2016).

8 N.A. Chuna and M. Maryono, Preliminary Evaluation of Method to Monitor Landfills Resilience against Methane Emission, in: E3S Web Conf., (2018).

9 J. Said and M. Maryono, Motivation and Perception of Tourists as Push and Pull Factors to Visit National Park, in: E3S Web Conf., (2018).

10 E.Y. Susanti, S. Adhi, and D.. Manar, Diponegoro J. Soc. Polit. Sci., 1-13 (2016). 
11 A. Khuzzaman, H. Rahmaya, and A. Neolaka, J. Menara, 8, 40-50 (2013).

12 I. Madon, D. Drev, and J. Likar, Data Br., 26, 1-12 (2019).

13 A. Mavropoulos, P. Cohen, and D. Greedy, "A roadmap for closing waste dumpsites the world's most polluted places", (2016).

14 S. Srigirisetty, T. Jayasri, and C. Netaji, Tech. Res. Organ, 4, 26-33 (2017).

15 H. Aziz and S. Hosseini, Brunei Darussalam J. Technol. Commer, 6, 44-71 (2012).

16 L.S. dos Muchangos and A. Tokai, Sci. African, 10, 1-10 (2020).

17 S. Manfredi and T.H. Christensen, Waste Manag., 29, 32-43 (2009).

18 N. Nurhadi, J. Windarta, and D. Ginting, J. Energi Baru Dan Terbarukan, 1, 19-25 (2020).

19 R.A.A. Verheem and J.A.M.N. Tonk, Impact Assess. Proj. Apprais., 18, 177-182 (2000).

20 R. Sadler, B; Verheem, "Strategic Environmental Assessment: Status, Challenges and Future Directions", Ministry of Housing, Spatial Planning and the Environment (1996).

21 Partidario, Environ. Impact Assess. Rev., 16, (1996).

22 T.B. Fischer, Environ. Impact Assess. Rev., 19, 143-173 (1999).

23 N. Um, Y.Y. Kang, K.H. Kim, S.K. Shin, and Y. Lee, Waste Manag., 82, 129-138 (2018). 